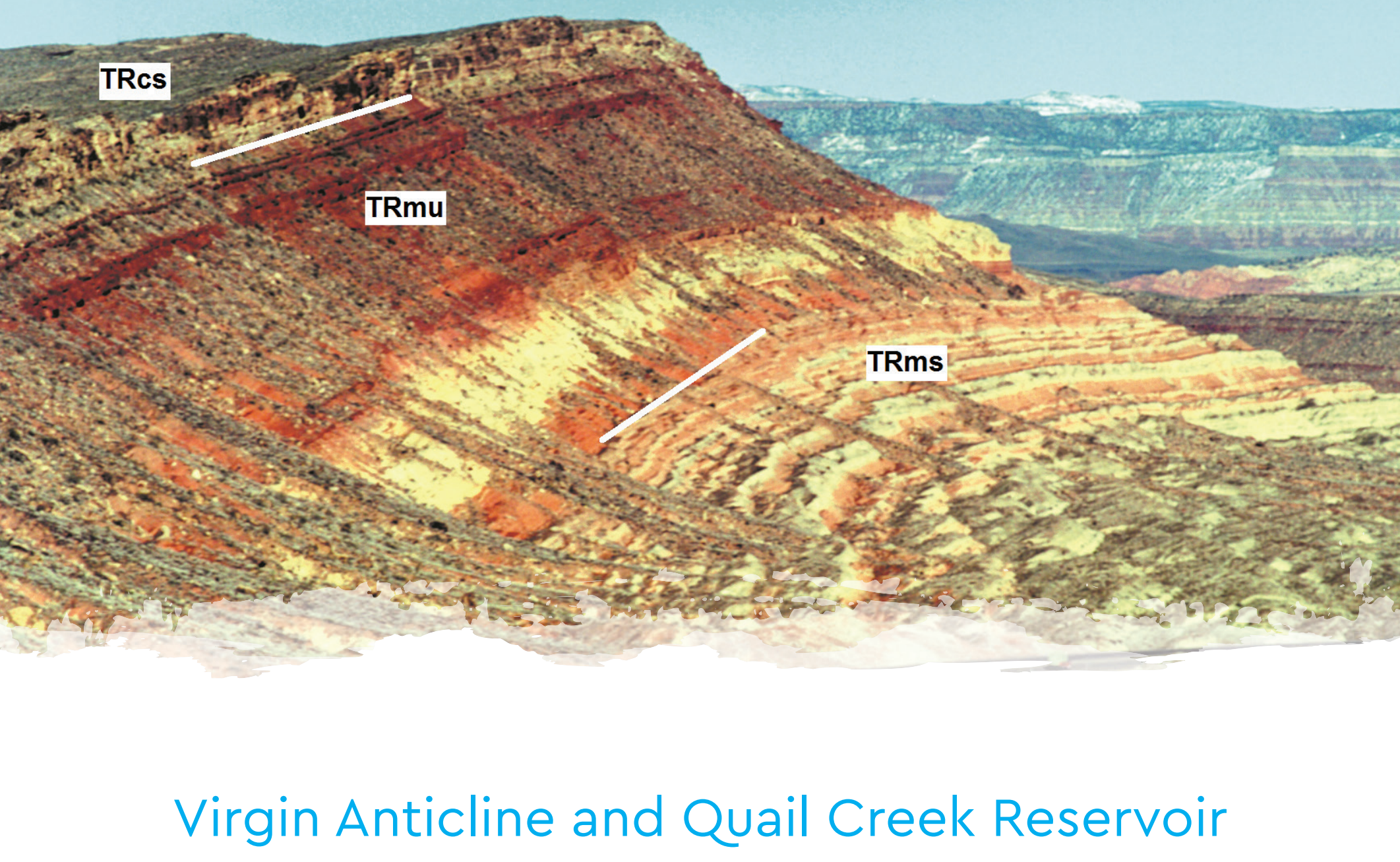

\title{
Virgin Anticline and Quail Creek Reservoir
}

Robert F. Biek

Utah Geological Survey, P.O. Box 146100, Salt Lake City, UT 84114-6100

bobbiek@utah.gov

\section{Utah Geosites \\ 2019}

Utah Geological Association Publication 48

M. Milligan, R.F. Biek, P. Inkenbrandt, and P. Nielsen, editors

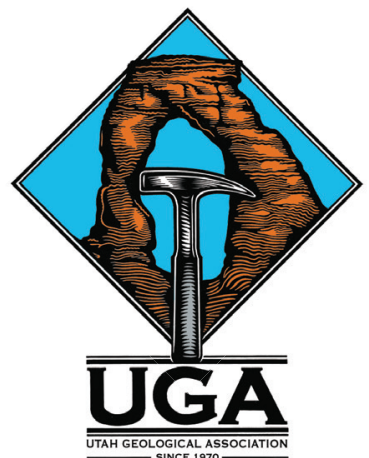




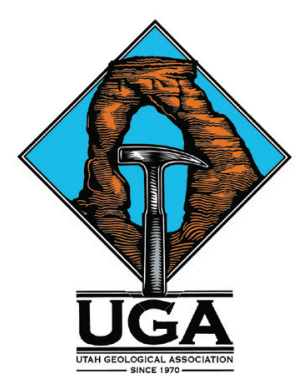

\section{Utah Geosites} 2019

\section{Utah Geological Association Publication 48}

M. Milligan, R.F. Biek, P. Inkenbrandt, and P. Nielsen, editors

Utah Geosites showcases some of Utah's spectacular geology, both little-known localities and sites seen by visitors to Utah's many national and state parks and monuments. The geosites reflect the interests of the many volunteers who wrote to share some of their favorite geologic sites. The list is eclectic and far from complete, and we hope that additional geosites will be added in the coming years. The Utah Geological Survey also maintains a list of geosites https://geology.utah.gov/apps/geosights/index.htm.

We thank the many authors for their geosite contributions, Utah Geological Association members who make annual UGA publications possible, and the American Association of Petroleum Geologists-Rocky Mountain Section Foundation for a generous grant for desktop publishing of these geosite papers.

Design and desktop publishing by Jenny Erickson, Graphic Designer, dutchiedesign.com, Salt Lake City, Utah.

This is an open-access article in which the Utah Geological Association permits unrestricted use, distribution, and reproduction of text and figures that are not noted as copyrighted, provided the original author and source are credited. See the Utah Geological Association website, www.utahgeology.org, and Creative Commons https://creativecommons.org/licenses/by/4.0/ for details.

Suggested citation for this geosite:

Biek, R.F., 2019, Virgin Anticline and Quail Creek Reservoir, in Milligan, M., Biek, R.F., Inkenbrandt, P., and Nielsen, P., editors, Utah Geosites: Utah Geological Association Publication 48, 8 p., https://doi.org/10.31711/geosites. v1i1.52.

\section{Presidents Message}

I have had the pleasure of working with many different geologists from all around the world. As I have traveled around Utah for work and pleasure, many times I have observed vehicles parked alongside the road with many people climbing around an outcrop or walking up a trail in a canyon. Whether these people are from Utah or from another state or country, they all are quick to mention to me how wonderful our geology is here in Utah.

Utah is at the junction of several different geological provinces. We have the Basin and Range to the west and the Central Utah Hingeline and Thrust Belt down the middle. The Uinta Mountains have outcrops of some of the oldest sedimentary rock in Utah. Utah also has its share of young cinder cones and basaltic lava flows, and ancient laccoliths, stratovolcanoes, and plutonic rocks. The general public comes to Utah to experience our wonderful scenic geology throughout our state and national parks. Driving between our national and state parks is a breathtaking experience.

The "Utah Geosites" has been a great undertaking by many people. I wanted to involve as many people as we could in preparing this guidebook. We have had great response from authors that visit or work here in the state. Several authors have more than one site that they consider unique and want to share with the rest of us. I wanted to make the guidebook usable by geologists wanting to see outcrops and to the informed general public. The articles are well written and the editorial work on this guidebook has been top quality.

I would like to personally thank Mark Milligan, Bob Biek, and Paul Inkenbrandt for their editorial work on this guidebook. This guidebook could not have happened without their support. I would like to thank Jenny Erickson for doing the great desktop publishing and the many authors and reviewers that helped prepare the articles. Your work has been outstanding and will certainly showcase the many great places and geology of Utah. Last, but not least, Thank you to the American Association of Petroleum Geologists, Rocky Mountain Section Foundation for their financial support for this publication.

Guidebook 48 will hopefully be a dynamic document with the potential to add additional "geosites" in the future. I hope more authors will volunteer articles on their favorite sites. I would like to fill the map with locations so that a person or family looking at the map or articles will see a great location to read about and visit. Enjoy Guidebook 48 and enjoy the geology of Utah.

Peter J. Nielsen

2019 UGA President 


\section{INTRODUCTION}

The first thing most visitors to Quail Creek State Park notice, apart from the improbably blue and refreshing waters of the reservoir itself, are the brightly colored, layered rocks of the surrounding cliffs. In fact, Quail Creek State Park lies astride one of the most remarkable geologic features in southwestern Utah. The park lies cradled in the eroded core of the Virgin anticline, a long upwarp of folded rock that trends northeast through south-central Washington County. The fold is breached by erosion along its crest, creating a window into the geologic past (figure 1). Famous for its geology, the park is also infamous for the 1989 catastrophic collapse of the Quail Creek south dike, which unleashed a torrent of water and caused millions of dollars of damage.

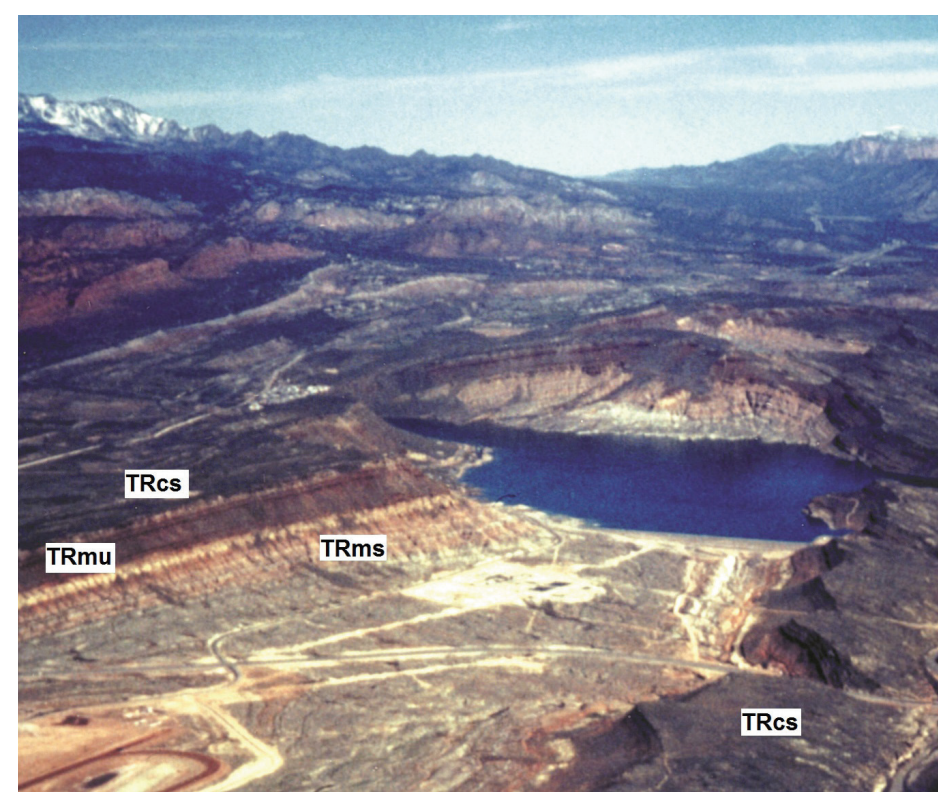

Figure 1. View northeast towards Quail Creek Reservoir nestled in the eroded core of the Virgin anticline. The flanks of the anticline are neatly outlined by the resistant Shinarump Conglomerate Member of the Chinle Formation (TRcs), below which are ledgy slopes of the upper red member of the Moenkopi Formation (TRmu). The "bacon-striped" Shnabkaib Member of the Moenkopi Formation (TRms) forms the eroded floor of the anticline. The snow-covered Pine Valley Mountains are on the skyline at left and the Kolob Canyons part of Zion National Park is on the skyline at right; State Route 9 cuts across the Virgin anticline at the bottom of the photograph. Photo courtesy of Janice Hayden.

\section{LOCATION}

One of the best places to see this geologic story is from the parking area at the west abutment of the Quail Creek south dam $\left(37^{\circ} 10.77\right.$ $\left.113^{\circ} 23.693^{\prime}\right)$. The park is accessible from the south via N. $5300 \mathrm{~W}$. off State Route 9, or from the north via Old Highway 91, a frontage road parallel to I-15 south of Leeds (figure 2). Figure 3 shows a simplified geologic map of the park and surrounding area, modified from Biek (2003a, 2003b). A kiosk with information about local geology and the problematic south dam is at the north end of the parking lot. A booklet, The Geology of Quail Creek State Park, is also available from the Utah Geological Survey (Biek, 1999).

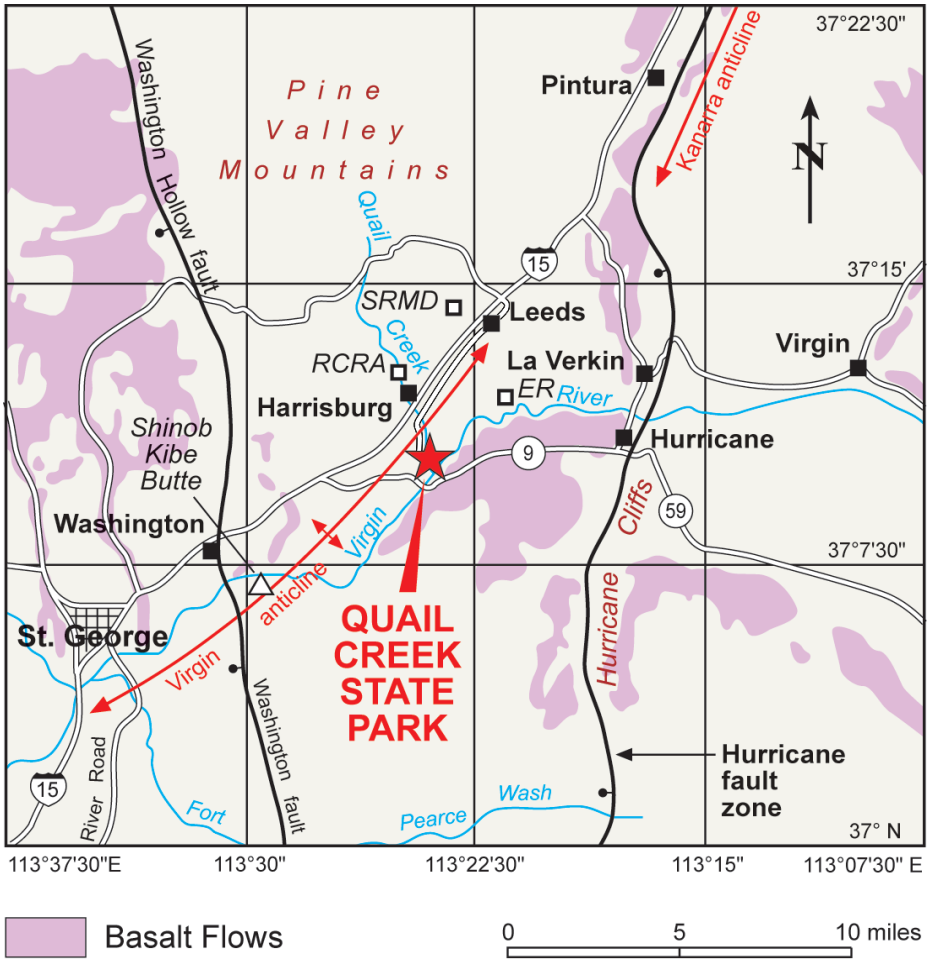

Figure 2. Location of Quail Creek State Park, Washington County, Utah. The parking area at the dam's west abutment offers a good place from which to view the geologic story of the park. From Biek (1999).

\section{STRUCTURE}

The greater St. George area, including Quail Creek State Park, lies in what geologists call the transition zone between the Basin and Range and Colorado Plateau physiographic provinces. The transition zone is characterized by strata and structures common to both the Basin and Range Province and Colorado Plateau. The brightly colored sedimentary rocks in the transition zone are characteristic of the generally flat-lying rocks of the Colorado Plateau, but they are locally deformed by both compressional forces associated with the Sevier orogeny (mountain-building episode) and more recent extensional forces associated with the formation of the Basin and Range Province. In southwestern Utah, the transition zone includes two major down-to-the-west fault zones that step down from the Colorado Plateau to the Basin and Range Province. The greater St. George area lies on the intermediate structural block thus created, bounded on the east by the Hurricane fault zone and on the west by the Gunlock-Grand Wash fault (figure 4).

\section{Virgin Anticline}

The Virgin anticline is a 30 -mile-long $(50 \mathrm{~km})$, northeast-trending, symmetrical fold that marks the eastern limit of significant Sevier-age compressional deformation in southwestern Utah. The flanks of the fold provide spectacular exposures of parts of the Lower Triassic Moenkopi Formation and overlying Upper Triassic Chinle Formation, including hogbacks of the Shinarump Conglomerate Member that dramatically outline the fold's shape 

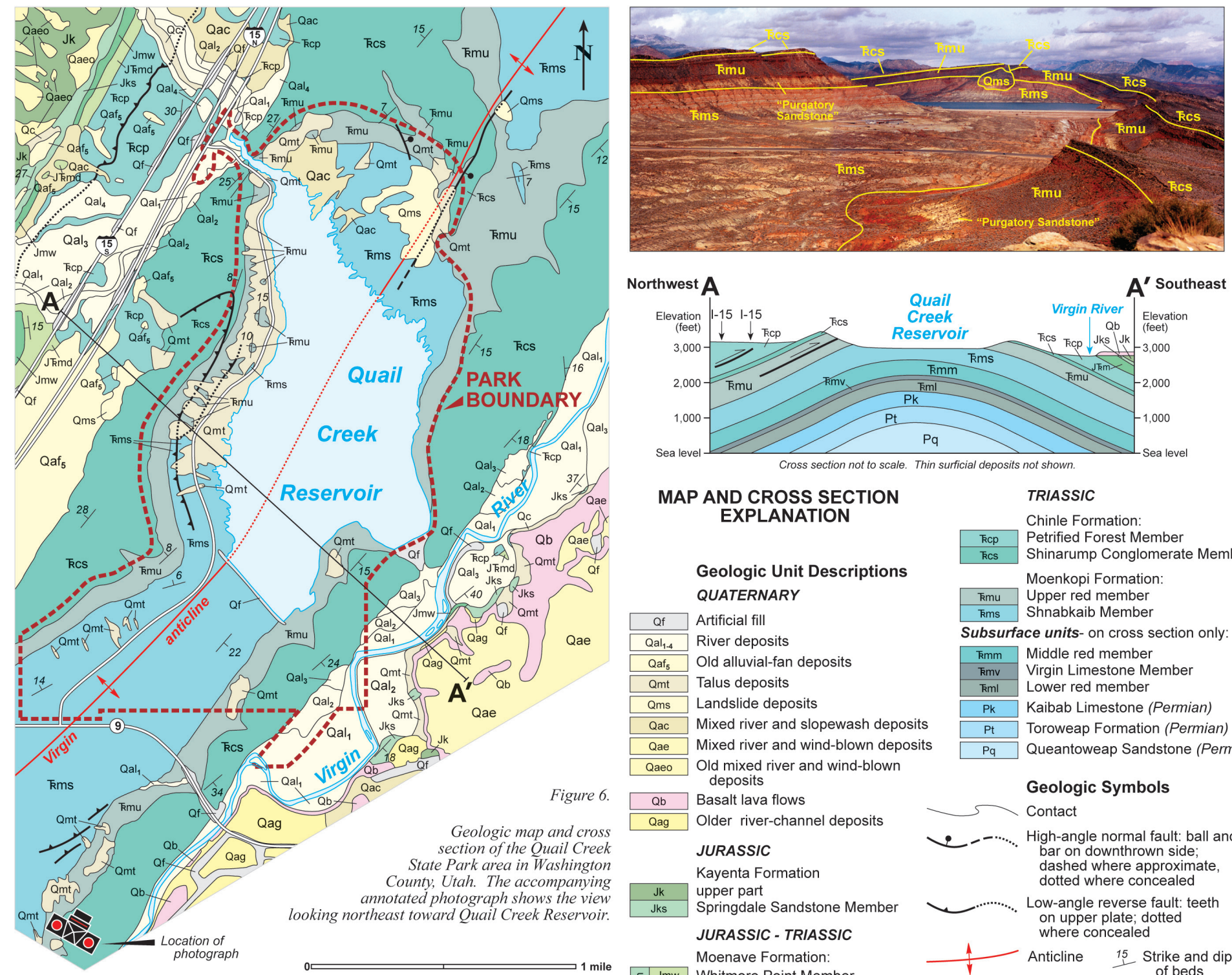
MAP AND CROSS SECTION
EXPLANATION

\section{Geologic Unit Descriptions} QUATERNARY

\begin{tabular}{|c|}
\hline Qf \\
\hline \hline Qal $_{1-4}$ \\
\hline \hline Qaf $_{5}$ \\
\hline \hline Qmt \\
\hline \hline Qms \\
\hline \hline Qac \\
\hline \hline Qae \\
\hline \hline Qaeo \\
\hline
\end{tabular}

Artificial fil

River deposits

Old alluvial-fan deposits

Talus deposits

Landslide deposits

Mixed river and slopewash deposits

Mixed river and wind-blown deposits

Old mixed river and wind-blown deposits

\begin{tabular}{|c|}
\hline $\mathrm{Qb}$ \\
\hline $\mathrm{Qag}$ \\
\hline \\
\hline $\mathrm{Jk}$ \\
\hline $\mathrm{Jks}$ \\
\hline
\end{tabular}

Basalt lava flows

Older river-channel deposits

JURASSIC

Kayenta Formation

upper part

Springdale Sandstone Member

JURASSIC - TRIASSIC

Moenave Formation:

Whitmore Point Member

Dinosaur Canyon Member
TRIASSIC

Chinle Formation:

Petrified Forest Member

Shinarump Conglomerate Member Moenkopi Formation: Upper red member

kms Shnabkaib Member

Subsurface units- on cross section only:

kmm Middle red member

kmv Virgin Limestone Member

$\mathrm{kml} \quad$ Lower red member

Pk Kaibab Limestone (Permian)

Pt Toroweap Formation (Permian)

$\mathrm{Pq}$ Queantoweap Sandstone (Permian)

\section{Geologic Symbols}

- 5 Contact

- $\cdots$, High-angle normal fault: ball and bar on downthrown side; dashed where approximate, dotted where concealed

Low-angle reverse fault: teeth on upper plate; dotted where concealed

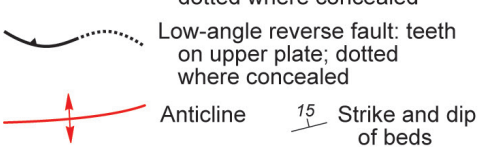

Figure 3. Geologic map and cross section of the Quail Creek State Park area. The photograph shows the view looking northeast towards Quail Creek Reservoir. From Biek (1999).

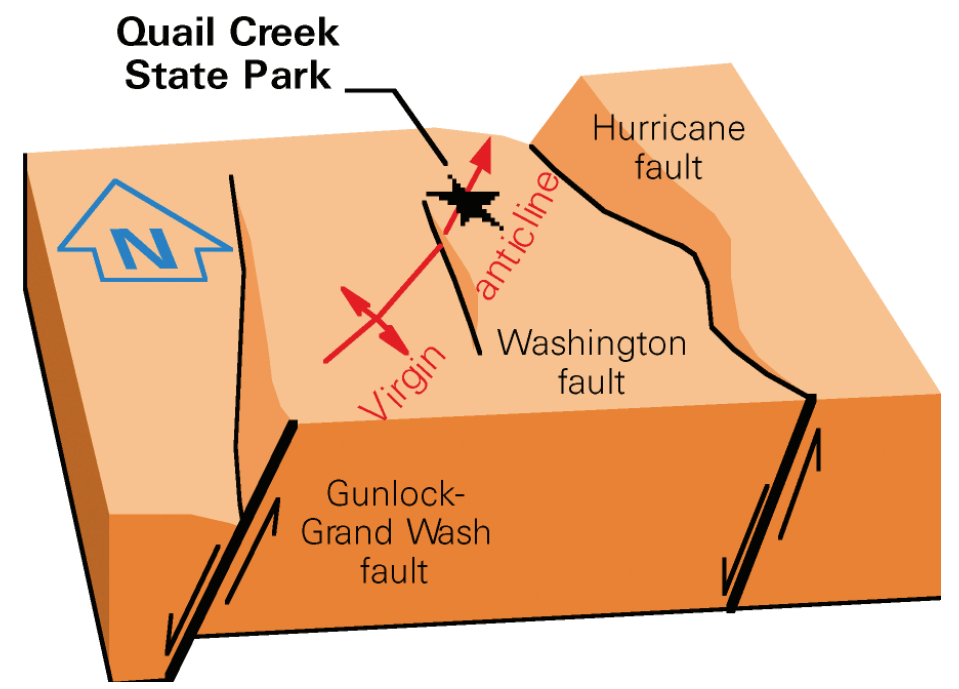

Figure 4. Schematic block diagram showing the relationship between the Hurricane and Gunlock-Grand Wash faults. Both faults are "normal" faults that formed during regional extension, allowing rocks on the west side of the faults to slip down relative to rocks on the east side.

Sidebar: The Sevier orogeny, or mountain-building episode, began in Utah by Middle Jurassic time, about 180 million years ago, as deformation associated with subduction of the Farallon oceanic plate along the western edge of North America spread eastward into western Utah (DeCelles, 2004). These eastward-directed compressional forces created the Sevier orogenic belt and associated broad deformation zone, which consists of, from west to east, a thrust belt with wedge-top basins, foredeep basin, forebulge, and back-bulge basin (DeCelles, 2004; Willis, 1999, 2000) (figure 5). Each of these four parts of the thrust system migrated eastward over time, and each created unique environments of deposition or erosion until the end of the orogeny about 40 million years ago. 


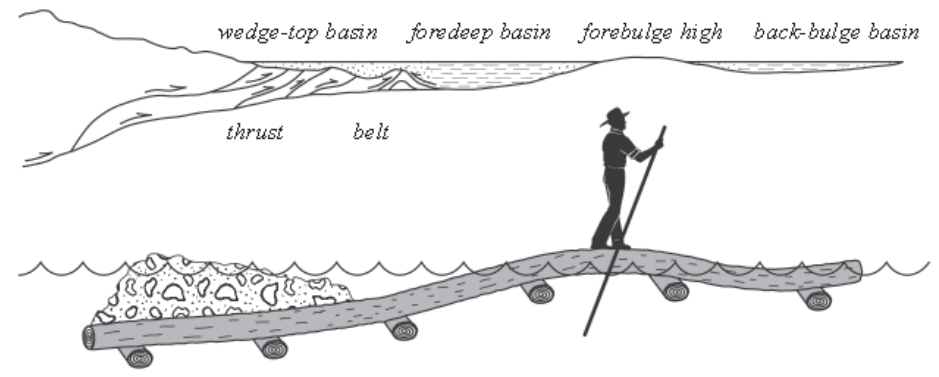

Figure 5. Typical parts of a thrust system. The thickened, eastward-moving, leading-edge thrust wedge on the left overloads the Earth's crust, which flexes in response, similar to loading rock on a wooden raft floating on water. In Utah, the entire thrust system migrated eastward over time during the middle Mesozoic to early Tertiary, but this simple pattern is commonly complicated due to variations in crustal strength and pre-existing faults. From Willis (1999).

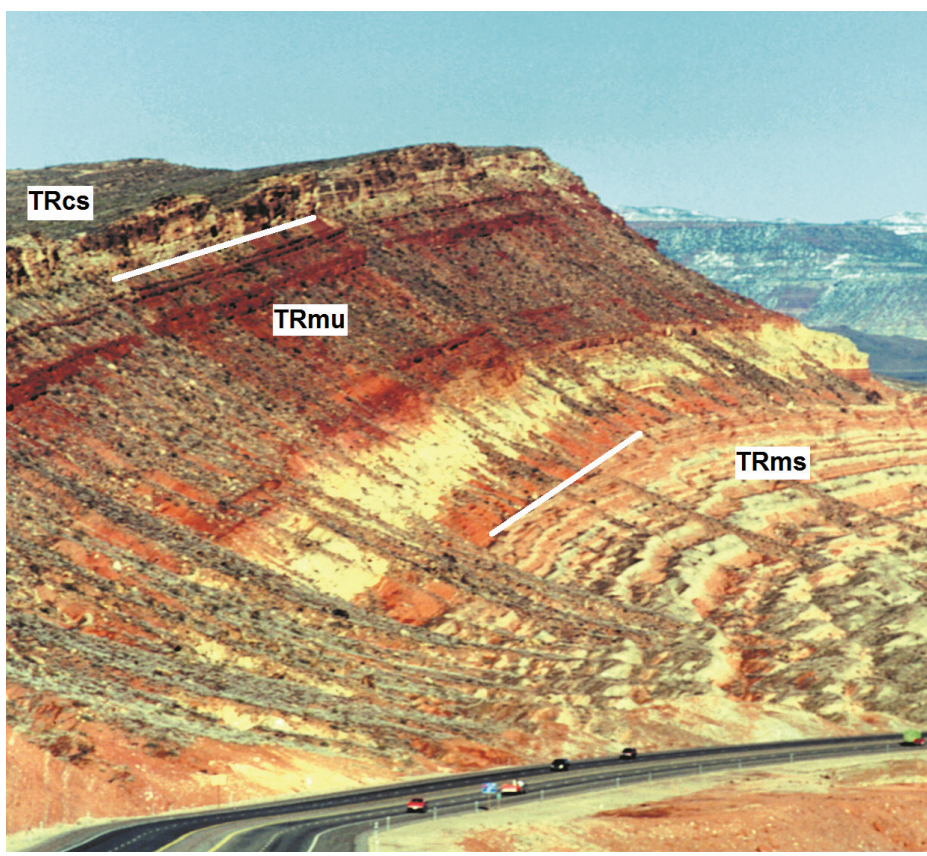

Figure 6. View north at a brightly colored hillside of Shnabkaib (TRms), upper red (TRmu), and Shinarump (TRcs) strata just north of Utah Highway 9, immediately south of Quail Creek State Park. These are the bedrock units seen surrounding Quail Creek Reservoir. Note the "bacon-striped" appearance of the Shnabkaib Member; the yellowish-brown sandstone, locally known as the "Purgatory Sandstone," near the base of the upper red member; and the cliff-forming Shinarump Conglomerate. A veneer of talus locally conceals bedrock. From Biek (1999). (figure 6). Along the northern reaches of the anticline, the carapace of Shinarump stands in dramatic relief above the Virgin River lowlands (figure 7). The anticline has three structural domes along its length. From south to north these are Bloomington Dome, Washington Dome, and Harrisburg Dome, each of which exposes gypsum-bearing Lower Permian Harrisburg Member of the Kaibab Formation. Several west-dipping thrust faults repeat Triassic and Lower Jurassic strata on the northwest flank of the anticline near Leeds (see the Silver Reef mining district geosite for more detail). The fold formed during the height of the Sevier orogeny, about 85 to 72 million years ago, above an east-directed blind thrust fault that soles into Cambrian strata (Davis, 1999; Hurlow and Biek, 2003).

\section{STRATIGRAPHY Moenkopi Formation}

The Moenkopi Formation of southwestern Utah, with its alternating reddish-brown, white, and gray layers, documents shallow-marine sedimentation along the western margin of the Pangean supercontinent, when what is now Utah lay close to the equator. The Moenkopi consists of three transgressive members (the Timpoweap, Virgin Limestone, and Shnabkaib Members, which thicken westward and record an interval of sea-level rise), each of which is overlain by an informally named regressive red-bed member (the lower, middle, and upper red members, respectively, which thicken eastward and record sea-level fall and deposition in tidal-flat environments); the Rock Canyon Conglomerate Member locally forms the base of the Moenkopi Formation (Reeside and Bassler, 1921; Stewart and others, 1972a; Dubiel, 1994). These members thus record a series of incursions and retreats of a shallow ocean across a gently sloping continental shelf from about 245 to 240 million years ago, where sea-level changes of several feet translated into shoreline changes of many miles (Blakey and others, 1993; Dubiel, 1994). The Moenkopi Formation is collectively about 1700 feet thick in southwestern Utah, but only the upper two members-the Shnabkaib and upper red members-crop out in the park (Biek and others, 2009).

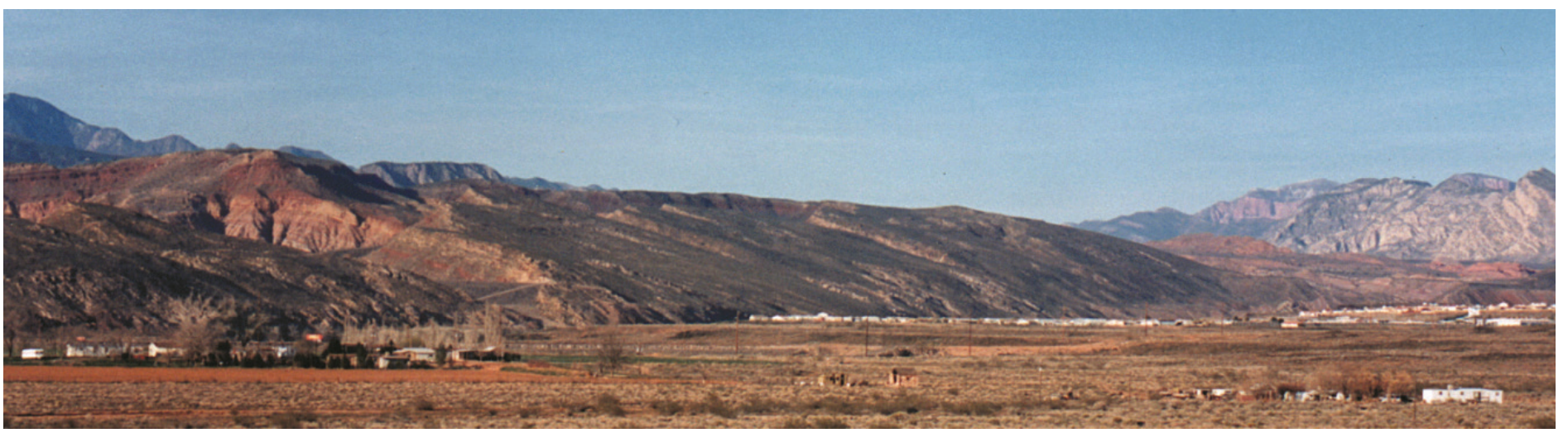

Figure 7. View north to the resistant Shinarump Conglomerate, which forms a whale-like carapace along the central part of the anticline northeast of Quail Creek State Park. The Hurricane Cliffs and Kolob Canyons part of Zion National Park are in the distance at right. 


\section{Shnabkaib Member}

The Shnabkaib (pronounced "shnab-kibe") Member forms striking red- and white-banded slopes and ledges around Quail Creek Reservoir. These rock layers are best seen above the west abutment of the Quail Creek south dam, and along the north shore of the reservoir. The banding is due to alternating layers of reddish-brown mudstone that weather to slopes, and slightly more resistant white gypsum and dolomite that weather to ridges and low ledges. The member is named for exposures at nearby Shinob Kibe butte, just southeast of Washington, which derives its name from the Piute words Shinob (Great Spirit) and Kaib (Mountain). The Shnabkaib Member contains about 30 percent gypsum as white nodules and layers up to several feet thick. The gypsum was deposited in a coastal-sabkha environment, a broad, nearly level area subject to high evaporation rates and periodic inundation by warm, shallow marine water. Gypsum is also present as coarser grained varieties known as selenite and satin spar that occur in cross-cutting veins.

The Shnabkaib Member is about 600 feet $(180 \mathrm{~m})$ thick at Quail Creek State Park, but thickens westward across the Utah hingeline, the former continental shelf of southwestern Utah. Its abundant gypsum, mudstone, and microbiolites (algal mounds) indicate deposition in a restricted-marine and coastal-sabkha environment; the member contains limestone in the Beaver Dam Mountains, indicating more open-marine conditions existed to the west (Stewart and others, 1972a).

\section{Upper red member}

The upper red member forms steep, ledgy slopes above the Shnabkaib Member and below the cliff-forming Shinarump Conglomerate. The upper red member consists of reddish-brown mudstone, siltstone, and sandstone. The base of the upper red member is marked by a prominent, cliff-forming, 100-foot-thick (30 m) yellowish-brown sandstone known locally as the "Purgatory Sandstone" (Biek and others, 2009). The upper red member is about 400 feet $(120 \mathrm{~m})$ thick, but thins to the west, away from the former continental margin. Common ripple marks and other features indicate that it was deposited in tidal-flat and coastal-plain environments (Stewart and others, 1972a).

\section{Chinle Formation}

In southwest Utah, the TR-3 regional unconformity (a pronounced gap in geologic time of about 10 million years; Pipiringos and O'Sullivan, 1978) separates Lower Triassic (Moenkopi Formation) and Upper Triassic (Chinle Formation) rocks and marks a change from mostly shallow-marine to continental sedimentation. This change occurred as oceanic island arcs continued to collide and accrete to the western Pangean margin in what is now California and southwestern Arizona during the Sonoman orogeny. These collisions deformed the western continental margin, forming a large chain of mountains and volcanoes. In Utah, by the Late Triassic, the environment changed from a passive continental margin to a large interior basin drained by north- and northwest-flowing rivers. Volcanic mud in rivers and airborne ash from the western volcanoes flowed and drifted east to the interior basin where it was deposited as the colorful layers of the Chinle Formation. The Chinle Formation of southwestern Utah has long been divided into the lower Shinarump Conglomerate Member and the upper Petrified Forest Member (Stewart and others, 1972b), but Petrified Forest strata may in fact contain beds better assigned to both younger and older Chinle Formation (Kirkland and others, 2014).

\section{Shinarump Conglomerate Member}

Because of its resistance to erosion, the Shinarump Conglomerate forms cliffs along the central portion of the Virgin anticline, including the cliffs around the west, north, and east sides of Quail Creek State Park. The Shinarump Conglomerate consists of yellowish-brown sandstone and pebbly sandstone deposited by generally north-flowing braided streams (figure 8) (Stewart and others, 1972b). The streams were probably similar to the modern Platte River and other rivers that drain eastward from the Rocky Mountains and that consist of shallow, interconnected or braided channels and intervening gravel bars. When Shinarump sediments were deposited in the Late Triassic, about 220 million years ago, this area was a gently sloping basin with mountains to the east and west. The small pebbles found in the Shinarump Conglomerate are mostly chert, quartzite, and quartz. Petrified wood is locally common in coarser, pebbly beds; the logs and limbs are remnants of trees deposited by floods. Much of the Shinarump, however, lacks pebbles and instead consists of sandstone. These sandstones are

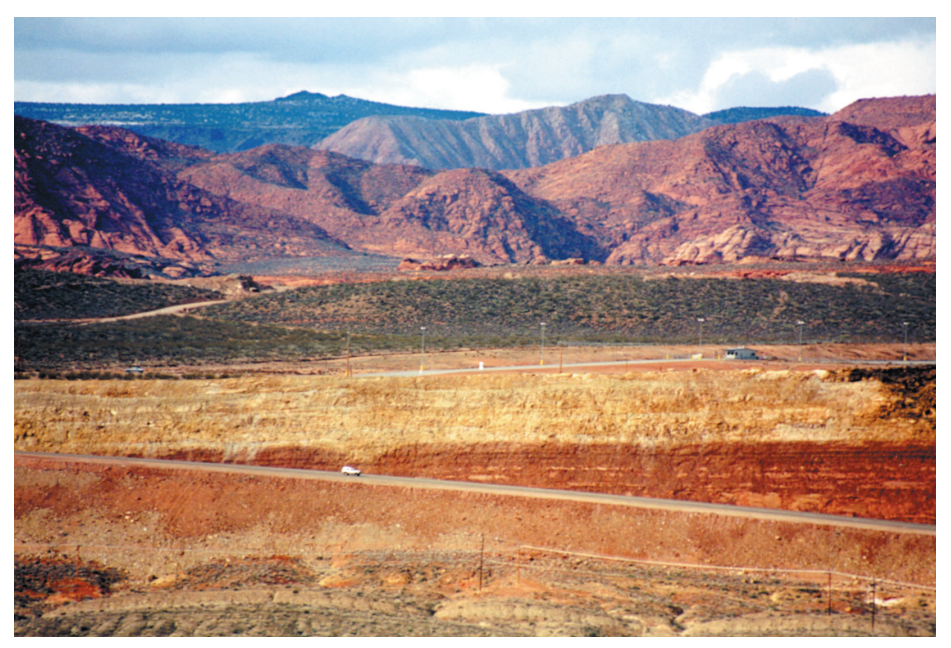

Figure 8. View west at a small channel (in Utah Highway 9 road cut just above the car) at the base of the Shinarump Conglomerate. Channels such as these are evidence of an unconformity - a surface denoting a gap in geologic timebetween the upper red member of the Moenkopi Formation and overlying Shinarump Conglomerate Member of the Chinle Formation. The channel shows that the area was exposed and erosion stripped off layers of sediment. This unconformity marks a pronounced change in depositional environments of these two rock units. Upper red strata were deposited principally in tidal flats whereas Shinarump strata were deposited by braided streams. 
commonly stained dark brown or black by iron-manganese oxides and locally form "picture stone" or "landscape stone." Shinarump strata are about 100 feet $(30 \mathrm{~m})$ thick at Quail Creek State Park.

\section{Petrified Forest Member}

Petrified Forest strata are widely exposed along the flanks of the Virgin anticline just outside the park boundaries. As might be surmised from its name, the member contains petrified wood; it also contains brightly colored clays-locally known as "blue clay" - that swell when wet and shrink when dry. These swelling clays are responsible for numerous building and road foundation problems in the area.

The Petrified Forest Member was deposited in floodplains, lakes, and meandering stream channels in a low, forested basin (Stewart and others, 1972b; Dubiel, 1994). Amphibians, reptiles (including the crocodile-like phytosaur), freshwater clams, snails, ostracods, and fish made their home on this once vast, coastal lowland, and petrified conifer trees are common in Chinle strata; fossil cycads, ferns, and horsetails are also known, as are dinosaur tracks (Stewart and others, 1972b; Blakey and others, 1993; Dubiel, 1994; DeCourten, 1998).

\section{CATASTROPHIC FAILURE OF QUAIL CREEK SOUTH DAM}

Although Quail Creek State Park is located in the middle of a truly exceptional geologic setting, the park is best known for its fishing and boating. Trout, bass, crappie, bullhead catfish, and bluegill attract anglers from throughout the west, and its warm waters make for a swimmer's paradise. The reservoir itself is operated by the Washington County Water Conservancy District for storage of Virgin River water. At its maximum pool elevation of 2985 feet (911 m), the lake covers 640 acres (one square mile or $2.6 \mathrm{~km}^{2}$ ) and stores 40,325 acre-feet (nearly 50,000,000 $\mathrm{m}^{3}$ ) of water. Most of the water is diverted from the Virgin River east of Hurricane and is piped about 8 miles (13 km) to the reservoir; this is done to avoid the salty water discharge at Pah Tempe Hot Springs between Hurricane and La Verkin. The annual yield of the reservoir is about 20,000 acre-feet $\left(20,000,000 \mathrm{~m}^{3}\right)$, an important part of the St. George basin water supply.

At 12:30 a.m. on January 1, 1989, the Quail Creek south dike collapsed catastrophically and unleashed a torrent of water, causing millions of dollars of damage. Fortunately, the downstream area was evacuated in time to avoid fatalities. Approximately 25,000 acre-feet $\left(31,000,000 \mathrm{~m}^{3}\right)$ of water-more than half of the reservoir's capacity-flowed through a breach in the dike over a 12-hour period (figure 9). The original Quail Creek south dike was a 78-foot-high, 2000-foot-long ( $24 \mathrm{~m}$ by $600 \mathrm{~m}$ ) earthen dam constructed in 1984. The dam was poorly designed and seepage under the dam occurred immediately after filling the reservoir. This seepage eroded the dam and foundation materials over the years despite efforts to seal the leaks. Ultimately, seepage and erosion of the dam and foundation materials accelerated until caving occurred on a developing opening in the dike. Frantic, last-minute efforts to stem the seepage were unsuccessful and the dike finally breached.

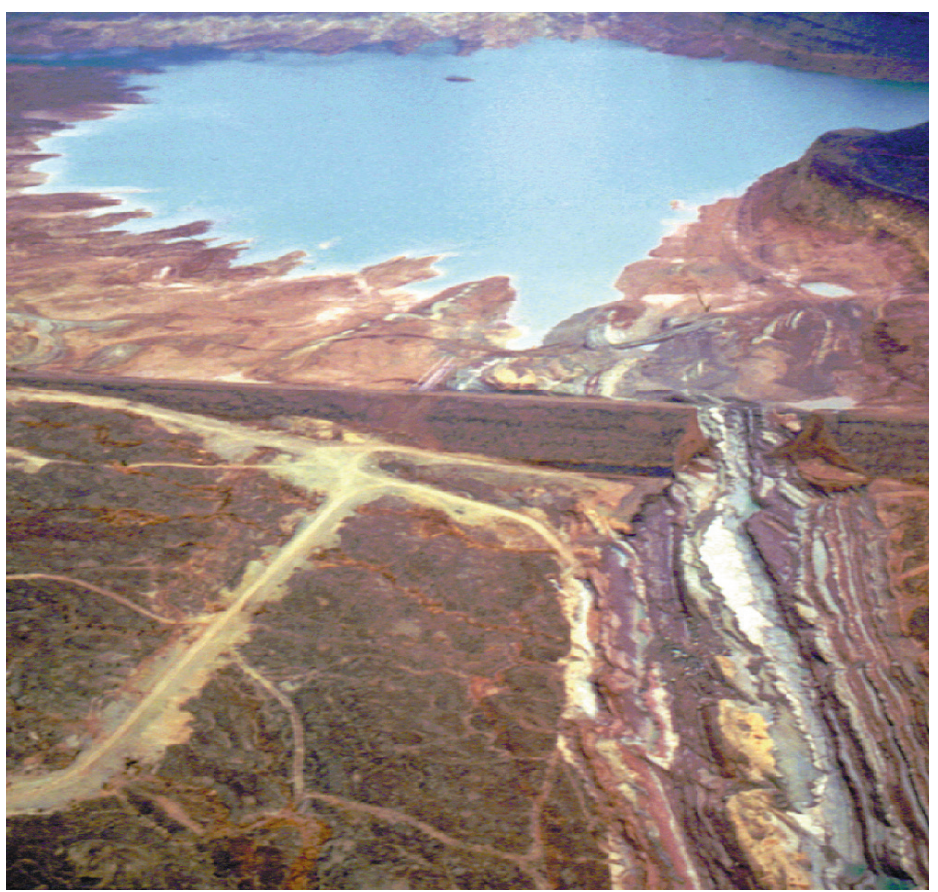

Figure 9. Quail Creek south dike, shortly after its catastrophic failure on January 1, 1989. Note how floodwaters scoured the bedrock clean of loose, overlying sediments just below the dike. Photo by Ben Everitt, Utah Division of Water Resources (retired).

After the dike's collapse, investigators found that participation of an engineering geologist was limited during the exploration, design, construction, and operation of the dike (O'Neill and Gourley, 1991; Gourley, 1992). They further found that the dike's failure was principally due to poor foundation design and construction. Simply put, the dike was built mostly on the highly jointed, gypsum-bearing Shnabkaib Member of the Moenkopi Formation (except the southeast abutment which lies on sandstone and siltstone of the upper red member). The joints allowed water to rapidly infiltrate bedrock under the dike, bringing it in contact with gypsum, which slowly dissolves in water.

The new dike, called the Quail Creek south dam, was completed in 1990 as a roller-compacted concrete gravity dam. The dimensions of the dam are basically the same as the old dike, except that it now includes a new impermeable cutoff trench as much as 75 feet $(23 \mathrm{~m})$ deep, which is designed to prevent water from seeping under the dam (figure 10). Evidence of the flood is still visible downstream from the new Quail Creek south dam, where the Shnabkaib Member was scoured clean of overlying loose bedrock and sediment. 


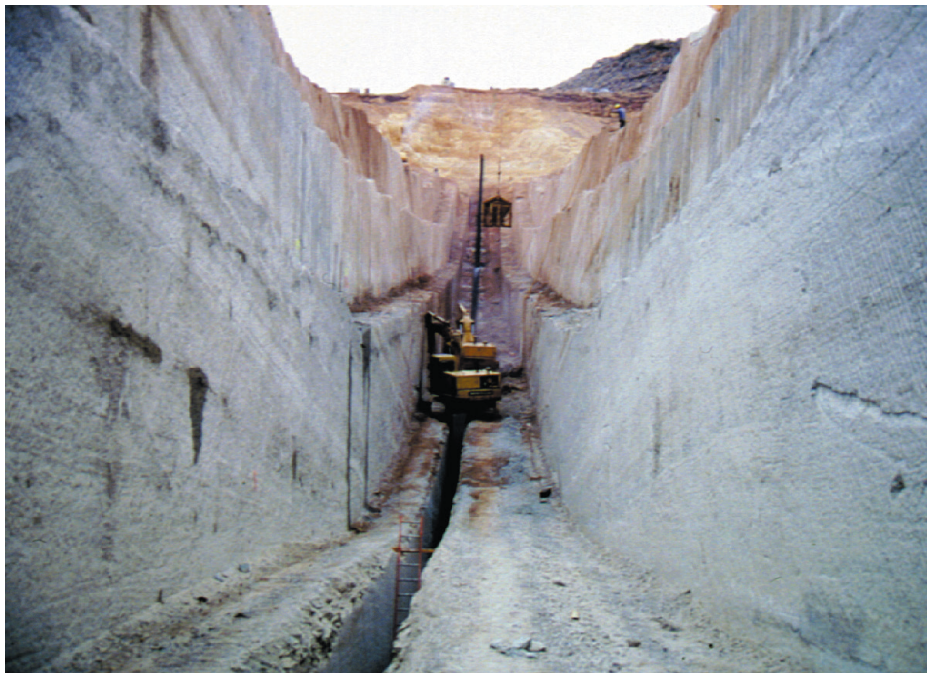

Figure 10. Cutoff trench being excavated at the bottom of the new Quail Creek south dam in January 1990. View east. Note seepage of water on left-side of trench. Photo by Bill Lund, Utah Geological Survey (retired).

\section{ACKNOWLEDGMENTS}

My knowledge of southwestern Utah geology comes from years of geologic mapping supported largely by the Utah Geological Survey and U.S. Geological Survey. As the acknowledgments of those many published geologic maps attest, I am indebted to a great many people for their help over the years. Thanks to Grant Willis, Mike Hylland, and Bill Keach (UGS) and Kimm Harty (UGS retired) for their insightful reviews.

\section{REFERENCES}

Biek, R.F., 1999, The geology of Quail Creek State Park: Utah Geological Survey Public Information Series 6, 21 p.

Biek, R.F., 2003a, Geologic map of the Hurricane quadrangle, Washington County, Utah: Utah Geological Survey Map 187, 61 p., 2 pls., scale 1:24,000.

Biek, R.F., 2003b, Geologic map of the Harrisburg Junction quadrangle, Washington County, Utah: Utah Geological Survey Map 191, 42 p., 2 pls., scale 1:24,000.

Biek, R.F., Rowley, P.D., Hayden, J.M., Hacker, D.B., Willis, G.C., Hintze, L.F., Anderson, R.E., and Brown, K.D., 2009, Geologic map of the St. George and east part of the Clover Mountains 30 ' x 60' quadrangles, Washington and Iron Counties, Utah: Utah Geological Survey Map 242, 101 p., 2 pls., scale 1:100,000.

Blakey, R.C., Bashem, E.L., and Cook, M.J., 1993, Early and Middle Triassic paleogeography, Colorado Plateau and vicinity, in Morales, M., editor, Aspects of Mesozoic geology and paleontology of the Colorado Plateau: Museum of Northern Arizona Bulletin 59, p. 13-26.

DeCelles, P.G., 2004, Late Jurassic to Eocene evolution of the Cordilleran thrust belt and foreland basin system, western U.S.A.: American Journal of Science, v. 304, p. 105-168.
Dubiel, R.F., 1994, Triassic deposystems, paleogeography, and paleoclimate of the Western Interior, in Caputo, M.V., Peterson, J.A., and Franczyk, K.J., editors, Mesozoic systems of the Rocky Mountain region, USA: Rocky Mountain Section of Society of Economic Paleontologists and Mineralogists, p. 133-168.

DeCourten, F., 1998, Dinosaurs of Utah: Salt Lake City, University of Utah Press, 300 p.

Gourley, C., 1992, Geological aspects of the Quail Creek dike failure, in Harty, K.M., editor, Engineering and environmental geology of southwestern Utah: Utah Geological Association Publication 21, p. 17-38.

Hurlow, H.A., and Biek, R.F., 2003, Geologic map of the Pintura quadrangle, Washington County, Utah: Utah Geological Survey Map 196, 20 p., 2 plates, scale 1:24,000.

Kirkland, J.I., Martz, J.W., DeBlieux, D.D., Santucci, V.L., Madsen, S.K., Wood, J.R., and Payne, N.M., 2014, Paleontological resource inventory \& monitoring, Chinle and Cedar Mountain Formations, Capitol Reef National Park, Utah: Utah Geological Survey Contract Report to the National Park Service prepared under cooperative agreement \#P13AC00601 Task \#P13AC01248, 128 p. plus appendices.

O’Neill, A.L., and Gourley, C., 1991, Geologic perspectives and cause of the Quail Creek dike failure: Bulletin of the Association of Engineering Geologists, v. 28, no. 2, p. 127-145.

Pipiringos, G.N., and O’Sullivan, R.B., 1978, Principal unconformities in Triassic and Jurassic rocks, Western Interior United States-a preliminary survey: U.S. Geological Survey Professional Paper 1035-A, 29 p.

Reeside, J.B., Jr., and Bassler, H., 1921, Stratigraphic sections in southwestern Utah and northwestern Arizona: U.S. Geological Survey Professional Paper 129-D, p. 53-77.

Stewart, J.H., Poole, F.G., and Wilson, R.F., 1972a, Stratigraphy and origin of the Triassic

Moenkopi Formation and related strata in the Colorado Plateau region, with a section on sedimentary petrology by R.A. Cadigan: U.S. Geological Survey Professional Paper 691, 195 p.

Stewart, J.H., Poole, F.G., and Wilson, R.F., 1972b, Stratigraphy and origin of the Chinle Formation and related Upper Triassic strata in the Colorado Plateau region, with a section on sedimentary petrology by R.A. Cadigan and on conglomerate studies by W. Thordarson, H.F. Albee, and J.H. Stewart: U.S. Geological Survey Professional Paper 690, 336 p.

Willis, G.C., 1999, The Utah thrust system-an overview, in Spangler, L.E., and Allen, C.J., editors, Geology of northern Utah and vicinity: Utah Geological Association Publication 27, p. 1-9.

Willis, G.C., 2000, Utah's Sevier thrust system: Utah Geological Survey, Survey Notes, v. 32, no. 1, p. 1-4. 